\title{
液状化問題の地形・地質的背景
}

若 松 加寿江*

\section{Geomorphological and Geological Settings for Soil Liquefaction}

\author{
Kazue WAKAMATSU*
}

\section{1. は じめに}

ゆるい飽和砂地盤では地震時に液状化現象が発生し， 構造物に甚大な被害をもたらすことがある。周知のよう に，このことが認識されるようになったのは1964年（昭

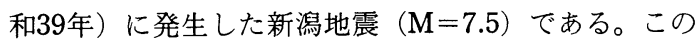
地震では, 鉄筋コンクリート造アパートの転倒, 道路橋 の落橋, 鉄道盛土や堤防の崩壊など多くの被害が発生し たが，これらのほとんどは液状化によるものであった。 また，この年には，海を隔てたアメリカでも夜状化によ る大規模な地すべりが発生し，アラスカ州アンカレッジ 市およびその周辺地域に甚大な被害を与えた。

1964年を契機として，地震時の地盤の液状化に関す る研究の必要性が強く認識され，日本とアメリカ合衆国 を中心として急速に進展した。しかし，これらの研究は 主に土質工学の分野でなされ, 地盤を物理的・力学的材 料として扱い，液状化を起こしやすい材料（土）やその 条件を調べることを目的とした室内実験や解析が主流で あった。

一方, 過去の地震における液状化発生の履歴の実態調 査も一部の研究者の手により行われてきた。筆者は18 年間, この液状化履歴に関する研究に携わってきた。地 盤の液状化が新潟地方に限った現象なのか否かを確かめ ることと, 液状化発生の法則性の追求が主たる目的であ った。研究を進めるうちに, わが国の沖積低地で普遍的 に生じていたことが明らかとなり, 各地の液状化発生地 点の地盤条件を調べ始めた。そこで，日本全土に分布す る極めて多数の液状化事例を分析するには, 単に材料と

\footnotetext{
*早稲田大学理工学研究所 Science and Engineering
} Research Laboratory, Waseda University
しての土ではなく，土層構造や地下水条件も含めた液状 化地盤の成因や地史，すなわち地形・地質的背景を知る ことの重要性を痛感した。

地質学は地球の生成史, 地殼の性質および構造などが 主要な研究対象であって，時間的には数 10 億年前ない し数百万年前に至る間の古い時代と, 地表から数 $\mathrm{km} \sim$ 数 $10 \mathrm{~km}$ の深さに及ぶいわゆる地壳部分が取り扱われ る1)。これに対し, 地形学は地質学の扱う地球形成史の 最後の部分を対象とし, 時間的には数百万年前よりこの 方現在時点に至るまでの間であり，地表の形態そのもの およびこれを構成する比較的新期の地層が取り扱われ る1)。したがって, 沖積低地で発生する液状化現象は, どちらかと言うと後者と大きなかかわりがあり, 特に最 新の地層の堆積状况を明確に反映している微地形と密接 に関係している。

本稿では，過去に液状化が広範囲に発生した主要な 3 平野を取り上げ, 地形・地質的条件, 特に微地形との 関連を調査した事例を紹介する。

\section{2. わが国における液状化発生地点の分布}

筆者は，古文書を含めた地震被害に関する各種の文献 の中から噴砂・噴水などの記述を捜し出したり，実際に 住民に聞き込み調査を行って，過去に液状化が発生した 地点を調べた。その結果，西暦416年から1989年までの 約1500年間に合計123の地震で，日本各地に液状化と考 えられる現象が発生していたことがわかった ${ }^{2)} 。$

図-1は，主な沖積平野や盆地における過去の液状化 発生回数を示している3 ${ }^{3)}$ 。わが国の地震被害に関する最 初の科学的な文献は「地震報告」(中央気象台発行の年 報）であり，刊行が開始されたのは1885年（明冶18年） 
A：1884年以前の歴史地霞により液状化

- : 1885年以降の地震により液状化

（）内の数字は既往地震による液状化発生回数を表す
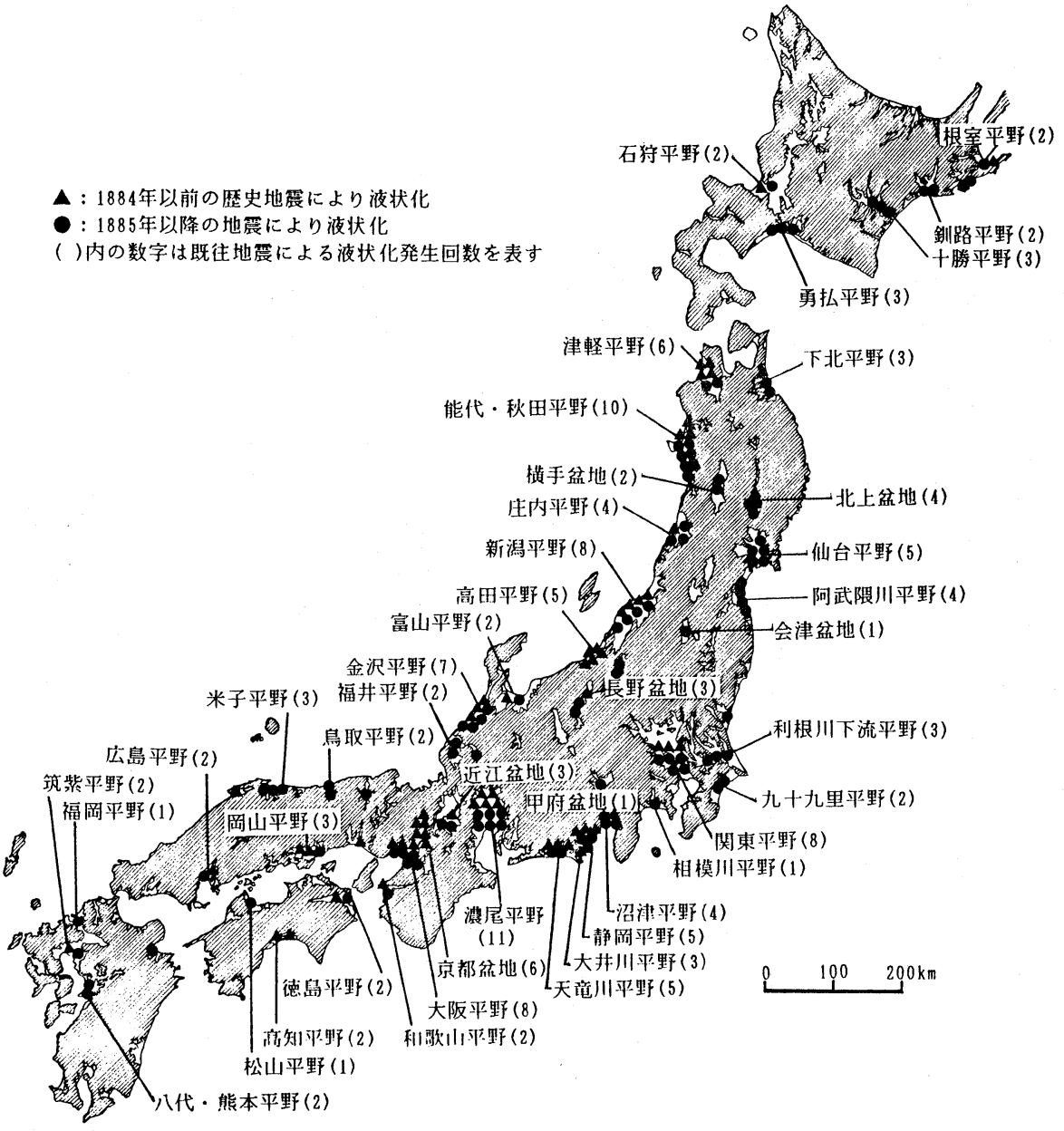

図-1 主な平野・盆地における液状化発生回数 $(416-1989)^{3)}$

のことである。このため図-1では，1884年以前の地震 を歴史地震として扱い，1885年以降の地震と区別して いる。図を見ると, 関東, 濃尾, 秋田, 仙台, 大阪の各 平野では, 1885年以降現在までの104年間だけでも 5 回 以上の地震で液状化が発生していることが分かる。

\section{3. 沖積平野における液状化事例の地形・地質的 背景}

\section{1 関東平野}

関東平野には, 利根川, 中川, 荒川, 多摩川などの河 川が形成した広大な冲積低地が発達している。地形的に は上流部から扇状地地帯, 自然堤防地帯, デルタ地帯の 3 つのゾーンに分けられ, わが国の河成沖積平野の典型 的様相を呈している。

図-2 は関東平野中心部における過去の液状化発生地
点を地形分類図上にプロットしたものである。液状化発 生地点は, その位置が比較的明確な1885年以降の地震 によるものを対象としている。内陸地震である東京湾北 部地震と西埼玉地震による液状化地点は, 震央に近い地 域に分布しているが，相模湾に震源を置く関東地震で は, 沖積層の厚い中川・古利根川沿いの埋没谷に沿って 液状化が発生している。

しかし, 個々の液状化発生地点の位置は微地形の影響 を強く受けていることがわかる。すなわち, 東京低地を 中心としたデルタ地帯では, 液状化は埋立地・干拓地お よび中川, 隅田川, 古隅田川沿いの地域で発生してい る。図-2では，図の大きさの都合で小規模な自然堤防 や旧河道は省略しているが，上記の河川沿岸の地点は大 部分が自然堤防や旧河道に当たっている。これに対し, デルタ一般面では液状化はほとんど発生していない。 


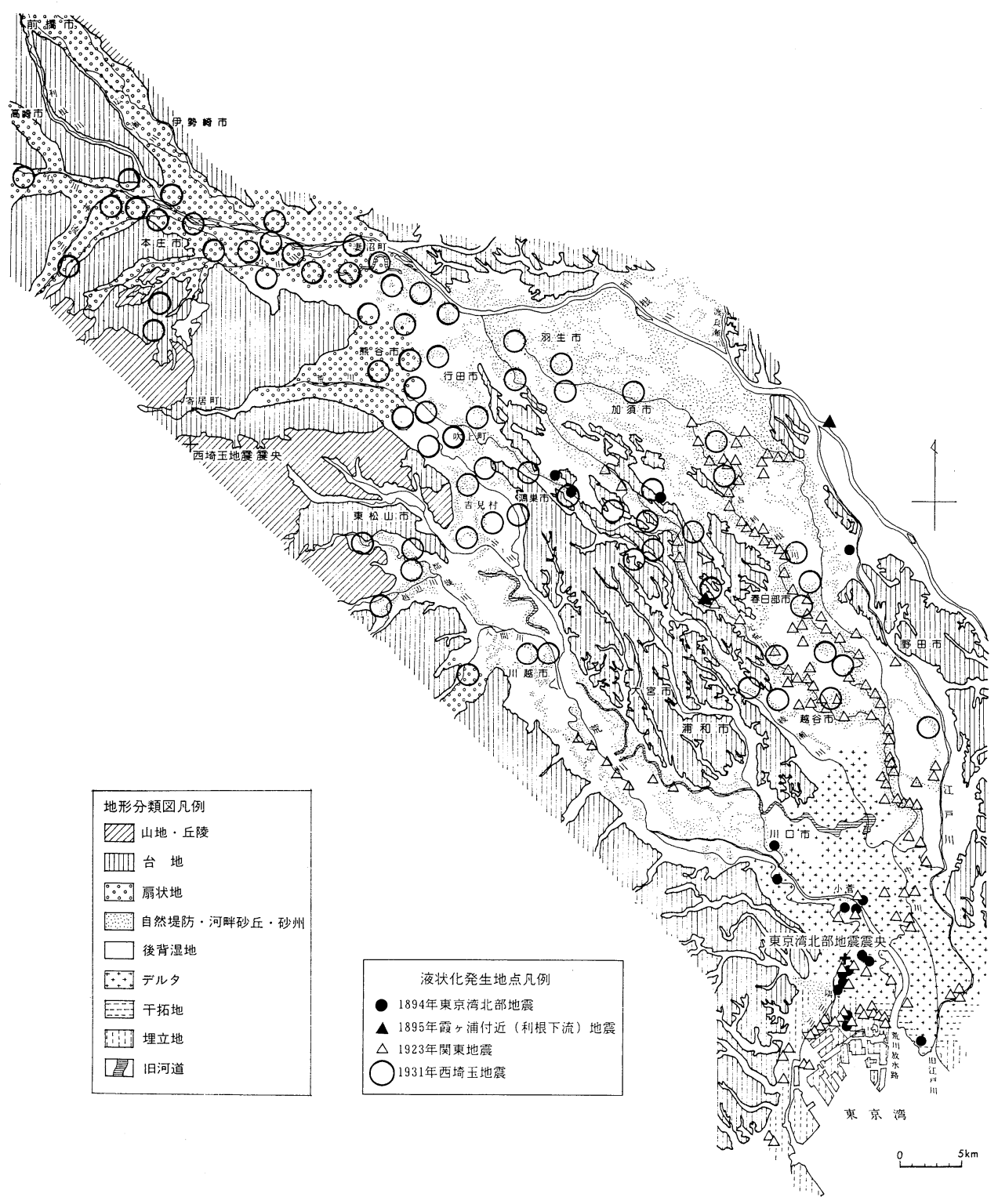

図-2関東平野における地形分類図と液状化発生地点

図 -3 は図 -2 の自然堤防地带における地形分類と関 東地震による液状化地点を拡大したものである。図中の 地割れは, 地質調查所の調查による噴砂・噴水を伴った 地割れの分布図 ${ }^{4}$ に基づいている。これらの地割れ群 は, 古利根川および元荒川に沿う自然堤防の分布を見事 に再現している。また, 地割れは河道の滑走斜面（堆積 側）に多く発生し, 攻撃斜面（侵食側）にはほとんど生 じていないこともわかる。

次に, 関東地震による液状化が古利根川・元荒川流域
に集中して発生し，荒川流域にはあまり生じなかった理 由について考えてみる。古利根川は1621年までの利根 川の本流であり，地下には50 $\mathrm{m}$ にも及゙深い埋没谷が 発達している。一般に, 地震動の増幅は軟弱層が厚いほ ど顕著であることから, 震央距離が同程度であっても荒 川沿岸より古利根川沿岸の方が地震動が強かったと想像 される。

第 2 の理由として, 自然堤防の規模や土質の違いが 考えられる。古利根川沿岸の自然堤防は主に利根川本流 


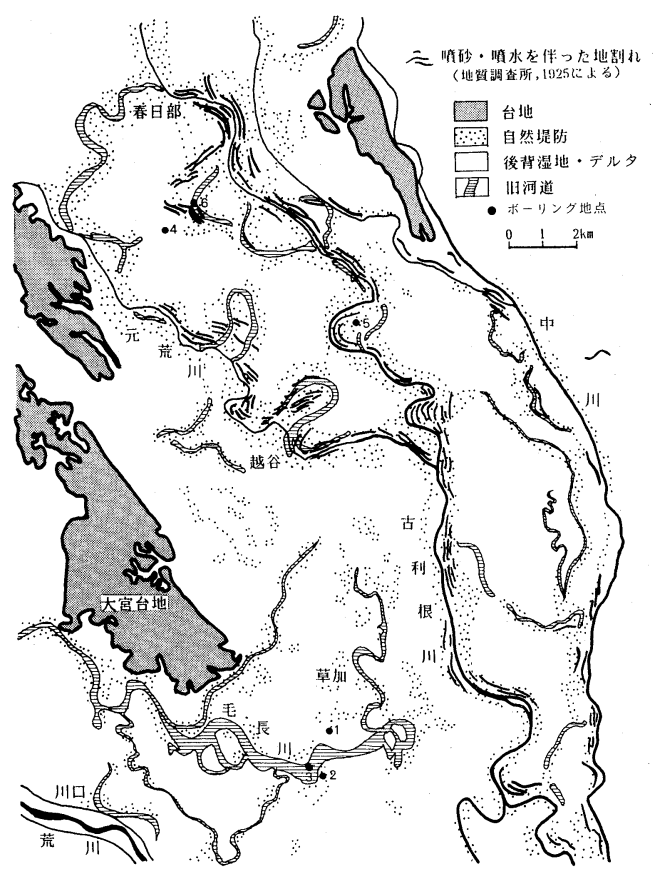

図-31923年関東地震による埼玉県越谷市・草加市付近 の微地形亡液状化発生地点

時代に形成されたもので, 連続性, 幅および比高などか ら見て日本最大の自然堤防である5)。これに対して，荒
川は鎌倉時代や江戸時代初期には綾瀬川や元荒川が本流 であり，現在の川筋に付け替えられたのは1629年のこ とである6)。このため, 現在の荒川沿岸には古利根川の ような大規模な自然堤防は発達していない。

自然堤防堆積物は一般に砂質土から成るが，厳密には 利根川系と荒川系では土質が異なる。大矢（1961）は 両者の河床堆積物と自然堤防堆積物の粒径を比較した結 果, 利根川系は砂質であるのに対し, 荒川系では利根川 系より粒子が細かく, 微細砂以下のものが占める割合が 多いことを指摘している7)。

また, この地域には, 往古の荒川が明瞭な旧河道を残 している。図-3の毛長川がそれである。旧河道では, 新潟地震の経験などから一般に液状化が発生しやすいと 言われている。このことから，筆者は 6 年ほど前に毛 長川沿いの地域で関東地震の体験者に聞き込及調査を行 った。しかし, 毛長川沿岸では, 噴砂・噴水などの地盤 変状は全く発生しなかったとのことであった。

図-4 に古利根川と毛長川流域のボーリング柱状図を 比較して示す。図中(1) (3)は毛長川流域の柱状図であ り, (4)〜 (6)は古利根川流域のものである。液状化が認め られなかった(1)のデルタと(4)の後背湿地では, 液状化を 起こしそうなゆるい砂が地表付近に見当たらない。(2)(5) の自然堤防之(3)(6)の旧河道の柱状図は, 毛長川, 古利根 川ともに地表付近にゆるい砂質土層が堆積している点で
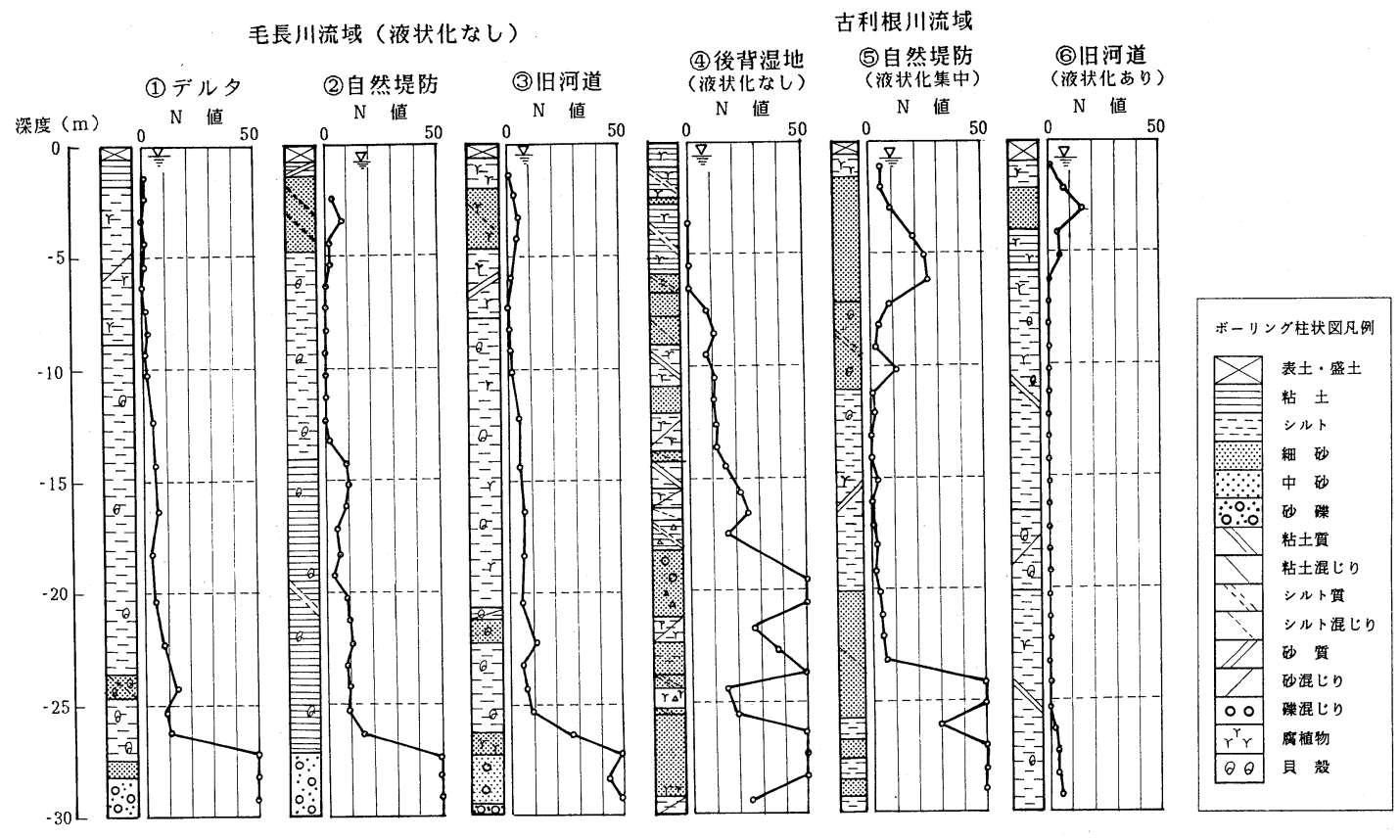

図 - 4 埼玉県越谷市・草加市付近の微地形と地盤条件との関係（ボーリング地点位置は図 -3 に示す） 


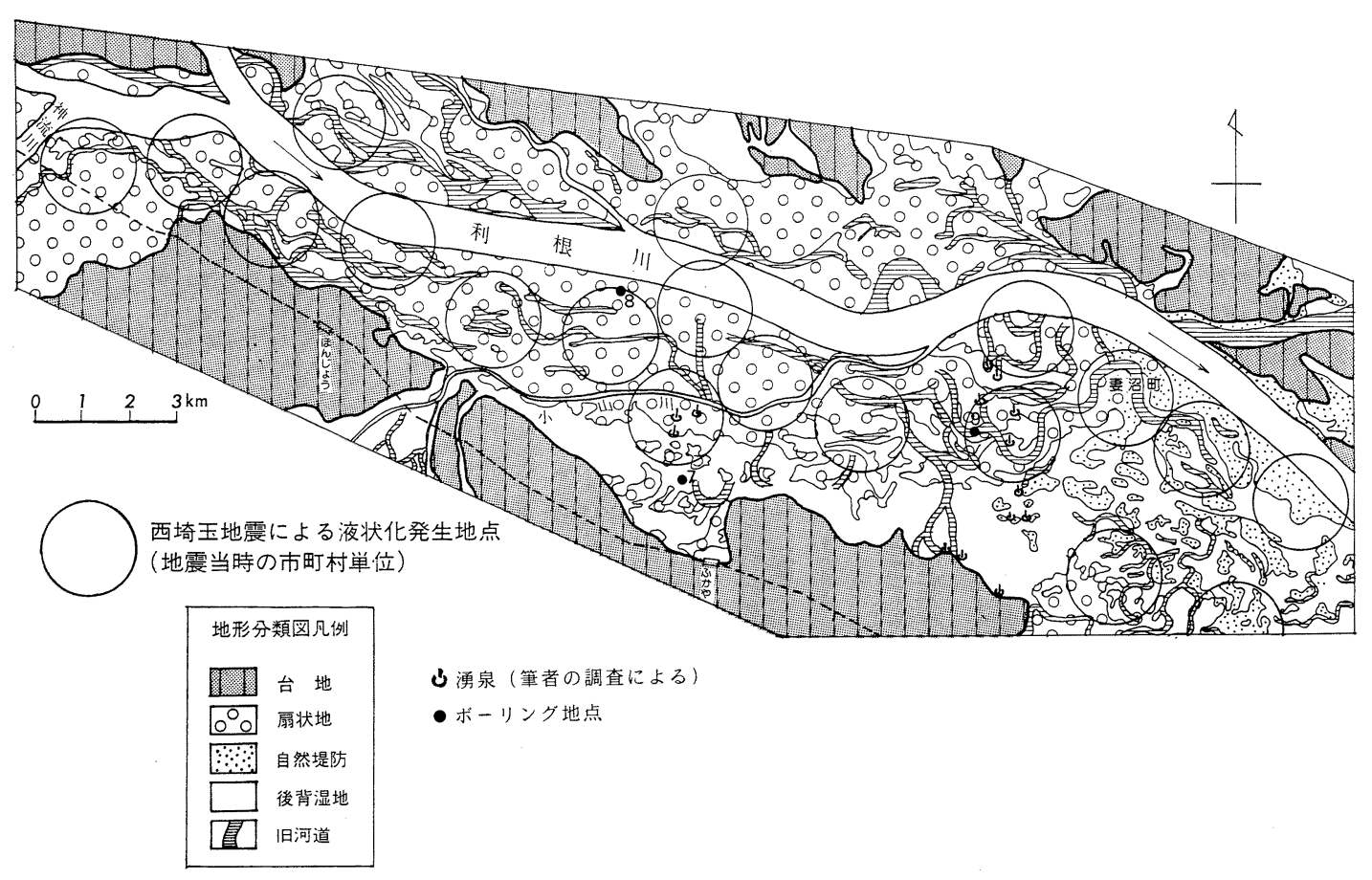

図－5 1931年西埼玉地震による埼玉県本庄市・深谷市付近の微地形8) と液状化発生地点

類似している。しかし，液状化が認められなかった毛長 川の砂層にはシルトが混入しており，粒度特性から見て 古利根川系に比べ液状化が生じにくいことがわかる。住 民の話によれば，毛長川沿岸の自然堤防は泥質のため野 菜畑に適さず，水稲作に改めたほどであるとのことであ る。

また, 前述の荒川同様, 沖積層の厚さの違いも液状化 発生の有無に影響したと考えられる。毛長川沿岸では厚 さが25〜30 m であるのに対し，古利根川沿岸では45〜 $50 \mathrm{~m}$ にも及んでいる。

図 5 は図 -2 に示した利根川の扇状地地帯の地形分 類8）と液状化発生地点を拡大したものである。この地域 には河道に沿って狭長な扇状地が形成されており, 背後 の台地との間は後背湿地となっている。液状化は扇状地 およびその旧河道付近で発生しており, 自然堤防地帯同 様, 後背湿地には生じていない。

図-6にこの地域の微地形ごとのボーリング柱状図を 示す。後背湿地では地表から $5 \mathrm{~m}$ 付近まで粘性土が堆 積しているのに対し, 扇状地や旧河道では地表面下浅い ところにゆるい砂層やあまり密でない砂磁層が存在す る。この地域では多量の地下水とともに砂碟を噴出した と報告されている ことから, 砂碟層の一部も液状化し たと推定される。砂磁層は一般に液状化が起こりにくい

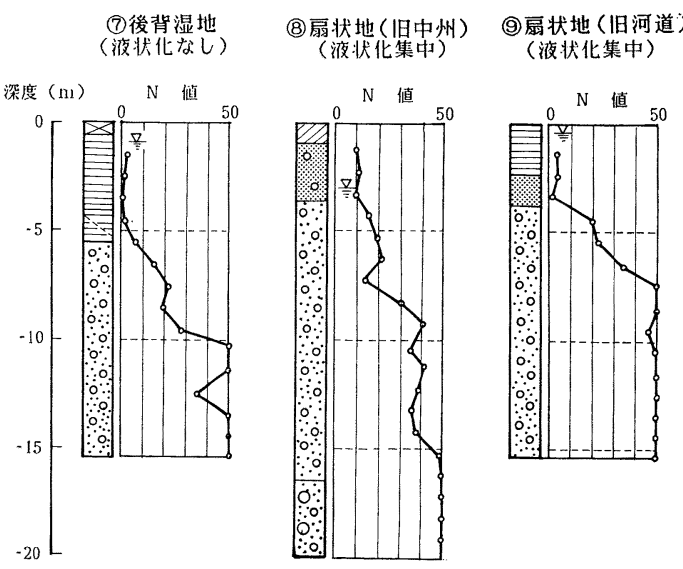

図-6 埼玉県本庄市・深谷市付近の微地形と地盤条件の 関係（ボーリング地点位置は図ー5 に示す）

と考えられているが, この地域の場合, 震央から近く地 震動が強かったと推定されること, かつ砂碩層が粘性土 で覆われているため地盤の排水性が悪く, 間隙水王が上 昇しやすい土層構造であったことが砂碩層の液状化を促 したと推察される。

なお, 扇状地の地下水位は一般に扇端部で浅く, 扇央 部で深い。利根川扇状地の場合, 液状化が全面的に発生 


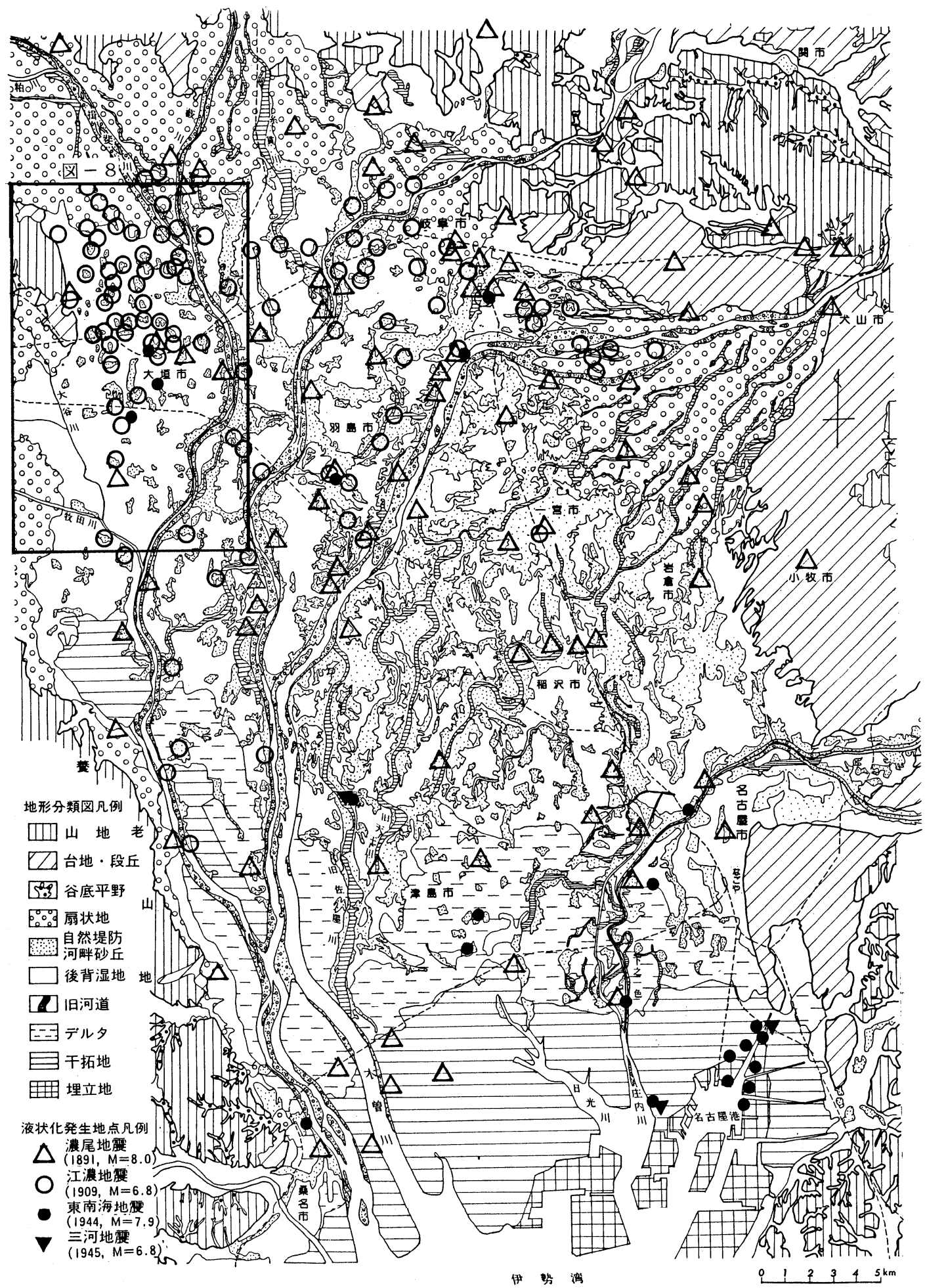

図 -7 濃尾平野の地形分類図と液状化発生地点 ${ }^{13)}$ 


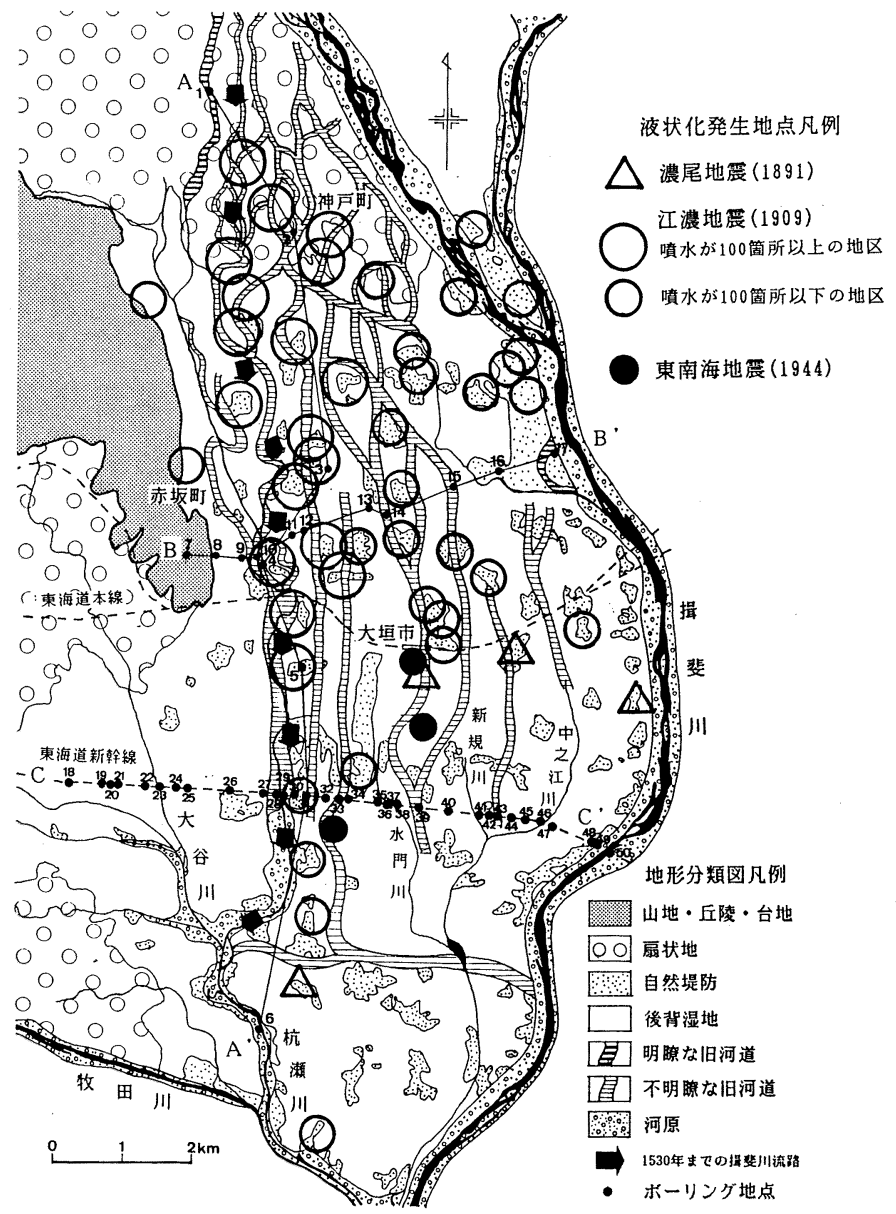

図-8 大垣付近の詳細地形分類図と液状化発生地点 ${ }^{13)}$

していることから，地下水の状況も調べた。全域につい ては調査できなかったが, 四ー5に示したように湧泉が 各所に認められた。この地域の自由地下水位等高線10) を見ると, 妻沼町より上流部では等高線は利根川に平行 ないし川を挟んで上流側に曲がっており, 地下水が台地 側から利根川に向かって流動する傾向を示している。こ のことからも, この扇状地の場合, 地下水位が全般に浅 く液状化が生じやすかったことがうかがわれる。

\section{2 濃尾平野}

濃尾平野は関東平野に次ぐわが国第 2 の大平野であ り, 地形的構成む類似している。

この平野では, 古来多くの地震に見舞われており, 液 状化を生じたと思われる地震の数も多い。図-7にはこ のうち1885年以降の主要な地震による液状化発生地点 を地形分類図 ${ }^{11)}$ 上にプロットした。液状化は, 関東平
野同様, 自然堤防周辺, 旧河道, 扇状地末端部, 埋立地 など, 微地形条件から推察して表層部に砂質土が堆積す るところに生じていることがわかる。

ところが，平野北西部の大垣付近は主として後背湿地 であり，軟弱粘性土地盤と推定されるにもかかわらず液 状化地点が極めて集中している。また，本地域は大垣自 噴帯12) と呼ばれる被圧地下水の湧泉帯に当たり, 地震 の際の泥砂の噴出が液状化によるものでなく, 被圧地下 水の噴出である可能性も考えられる。筆者は上記のこと を確かめるために，この地域の液状化地点の地形・地質 的背景を詳しく調査した ${ }^{13)}$ 。

図-8に, 大垣付近の地形分類図と液状化発生地点の 詳細を示す。空中写真判読等により詳細な微地形調査を 行った結果, 本地域の北半部には極めて不明瞭である が，点在する自然堤防に沿って幾筋もの旧河道が分布し 


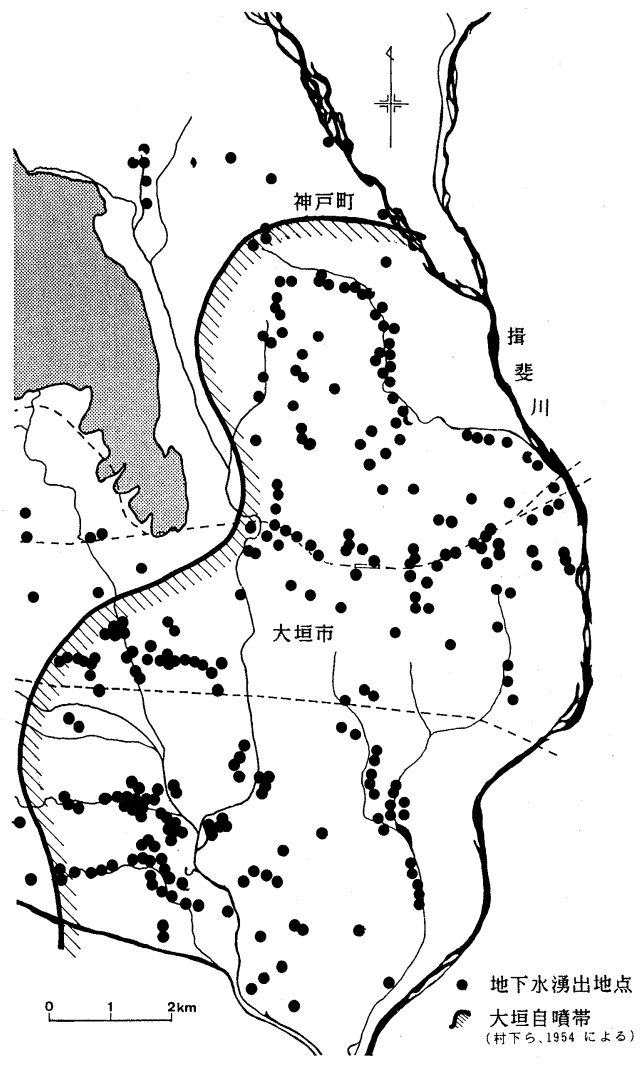

図-9 大垣自噴帯と地下水湧出地点 ${ }^{13)}$
ていることが明らかになった。また，これらの旧河道の 年代を調べた結果，上記の旧河道は1530年（享禄 3 年） までの揖斐川の本流の位置と一致することがわかった (図 -8 の矢印)。

一方, 被圧地下水の状況を知るために, 空中写真や明 治・大正期の地形図によって地下水湧出地点を抽出し た。その結果, 図-9に示すように, 涌水地点は大垣自 噴帯の簛囲内に高密度に分布していることがわかった。 しかし, 液状化発生地点と湧水地点の位置は必ずしも一 致しなかった。

次に，図-8に示した微地形と表層地質との関係をボ ーリング資料によって確認した。図ー10に示すように， 本調査地域の沖積層は第一礫層と呼ばれている砂礫層を 基底として北部で薄く数 $\mathrm{m}$, 南下するに従い厚さを増 し, 最南部で $40 \mathrm{~m}$ 余りの厚さで堆積している。南半部 すなわち東海道本線以南では汽水成層や海成層（上部砂 層・中部粘土層・下部砂層）が発達している。最上部陸 成層は厚い所で $10 \mathrm{~m}$ を超えており, 北部の扇状地帯で は主として砂碟であるが，自然堤防帯では砂碟から粘性 土へと漸移している。

図-11は東海道本線の北側における東西方向の地質 断面図である。この地域には海成層と思われる地層は認 められず，起伏の激しい基底礫層の上に最上部陸成層が 直接載っている。地表部は後背湿地性の軟弱な粘性土層 で覆われているが, 過去に一時河道や自然堤防であった ことを示す砂層・砂碟層を所々に挟んでいる。特に旧揖

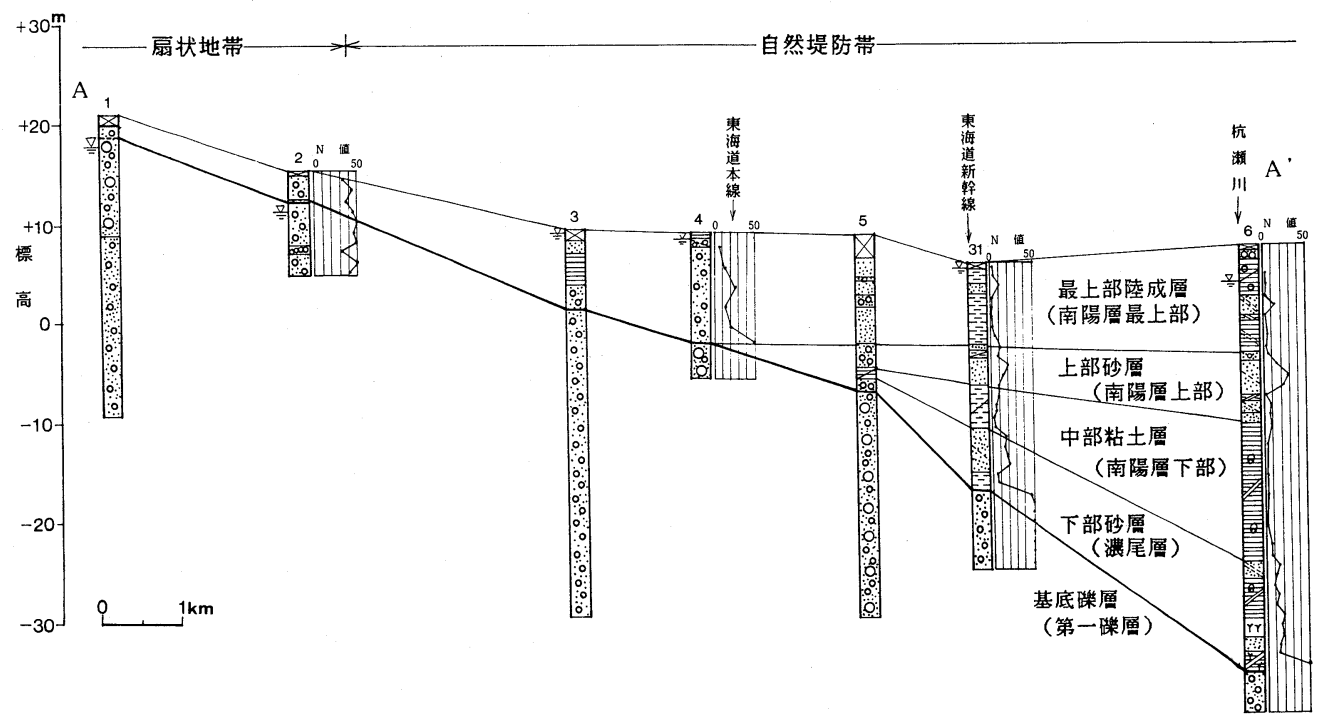

図-10 大垣付近の南北方向推定地層断面図 ${ }^{13)}$ (断面位置は図-8に示す) 

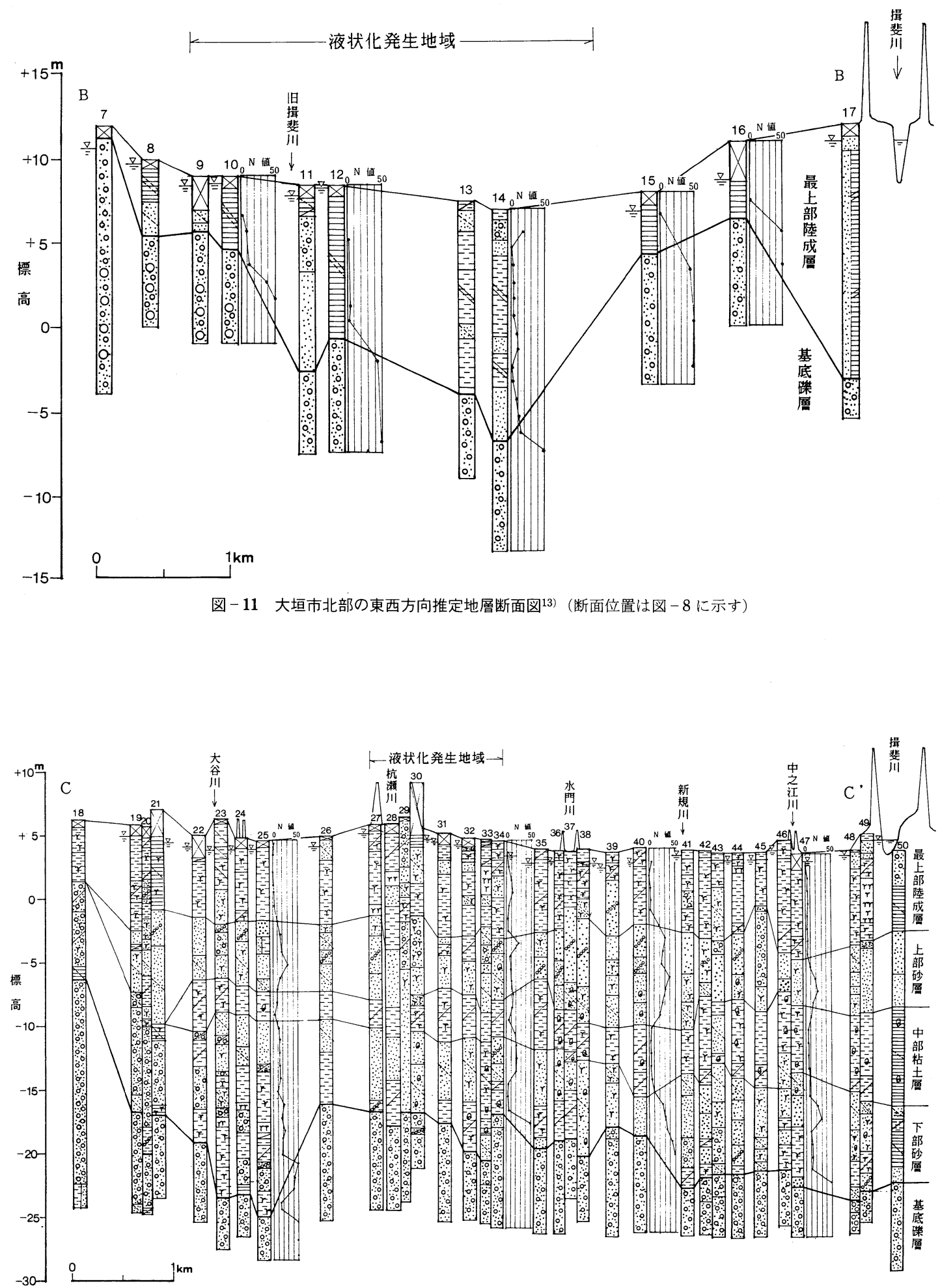

図-12 大垣市南部の東西方向推定地層断面図 ${ }^{13)}$ (断面位置は図-8に示す) 

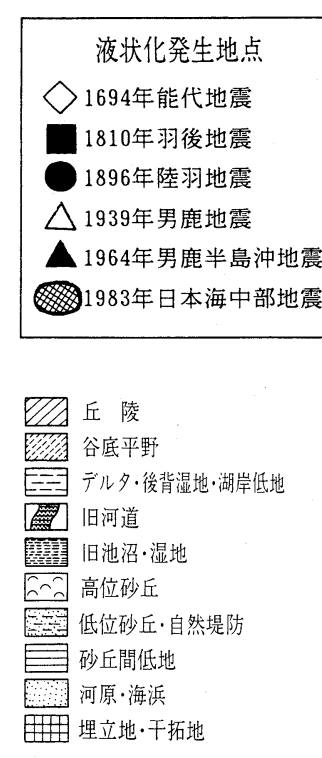

海

日
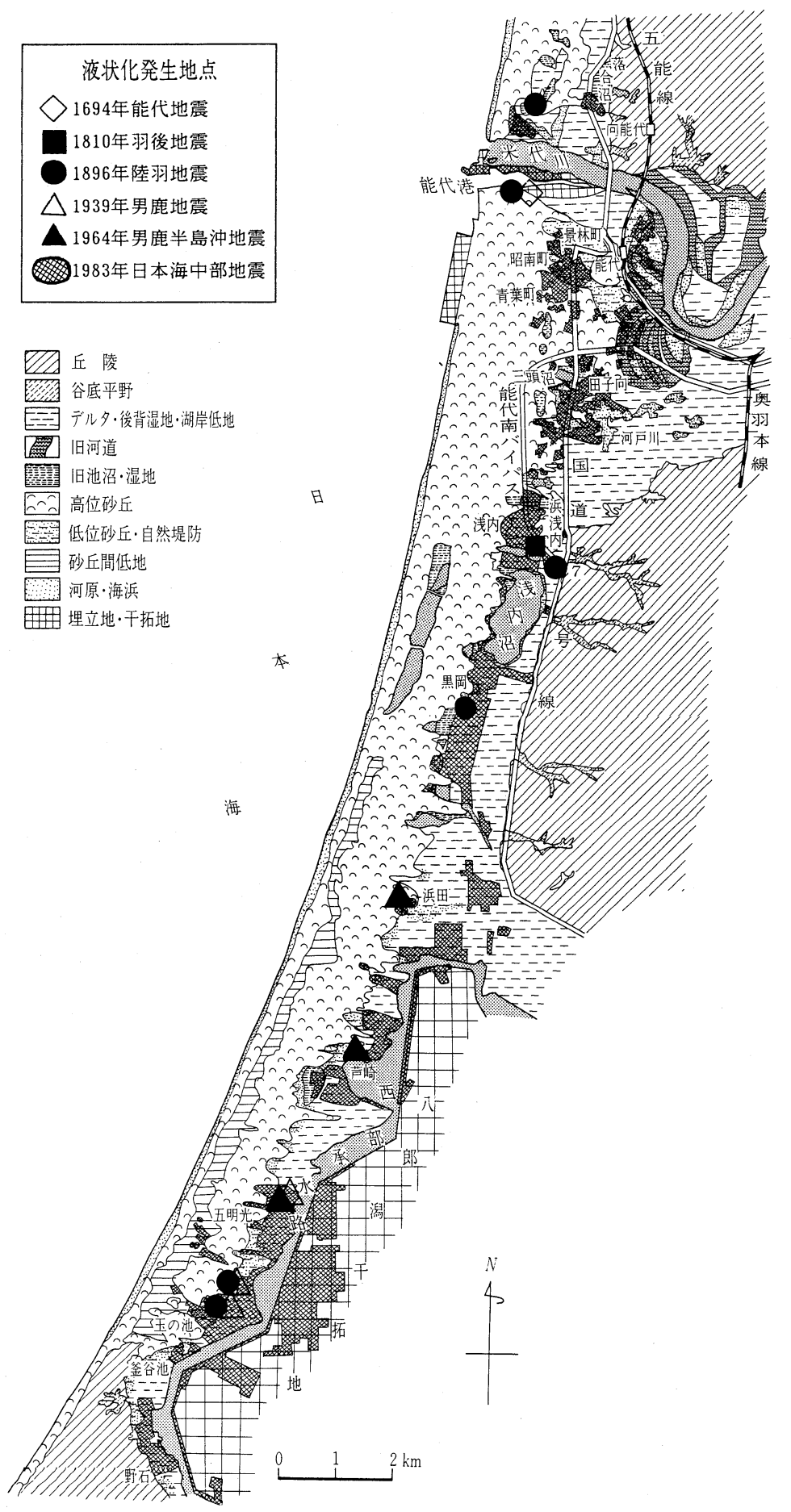

図-13 能代〜八郎潟西岸地域の地形分類図と液状化発生地点（文献15）に加筆） 


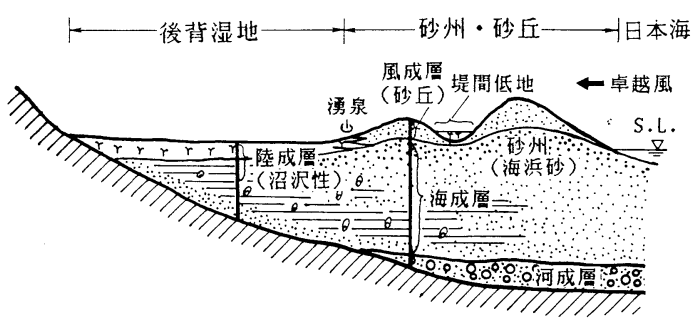

図-14 砂丘地帯の模式的断面図

斐川本流の流路と思われる辺り（No. 11）では，砂碟 層および砂層が $10 \mathrm{~m}$ 近く堆積しているのが認められる。 図-12は東海道新幹線沿いの地質断面図である。こ こでの最上部陸成層は全般に有機質で軟弱である。陸成 層の土質と微地形との対応を見ると，揖斐川や杭瀬川の 現河道 (No. 29, 50) では地表部は砂磷層で構成されて いる。自然堤防（No. 26，48，49）では，砂およびシル ト混じり砂である。その他の地点, すなわち図 -7 の地 形分類図で後背湿地と区分されているところでは，地表 面はシルトで覆われている。しかし, 四-8の詳細な地 形分類図で不明瞭な旧河道が分布する地点（No. 28〜 $34 ， 39 ， 43 ）$ のみに, 地表面下数 $\mathrm{m}$ に厚さ $1 \sim 4 \mathrm{~m}$ 程度 の砂層が伏在していることがわかる。地下水位は扇状地 末端から自然堤防地帯を通じて全般に浅く, ボーリング の孔内水位で G. L. $-1 \mathrm{~m}$ 前後である。

液状化発生地点と沖積層の分布を対比すると, 液状化 発生地点は海成層が見られない調査地域の北半部に集中 している。海成層のうち液状化の可能性が考えられる地 層は深さ $10 \mathrm{~m}$ 前後に存在する上部砂層であるが，この 地域の上部砂層の $\mathrm{N}$ 値は15 20以上と比較的締まって いることから液状化が起こりにくいと考えられる。たと え局部的に発生しても，厚い陸成層で履われているため にその影響は地表に現れなかったと思われる。

一方, 北半部に分布するのは最上部陸成層と基底砅層 である。基底碟層はこの地域の第一被圧地下水帯水層で あることから，泥砂や水の噴出が液状化によるものでな く被圧地下水の噴出とも考えられる。しかし噴出現象が 見られたのは，前述のように図-9に示した自噴帯のう ち北半部の地域であり，また涌水地点の分布ともはっき りした関係は認められない。液状化地点は, むしろ図一 8 に示した不明瞭な旧河道の分布と良く一致している。 特に江濃地震の際, 噴水が100か所以上で見られた地区 （図-8 中の大きい○）の分布と旧揖斐川本流の流路（同 図中の矢印）とは極めて良く合致している。このことか ら，この地域における噴出現象は被圧地下水の噴出では

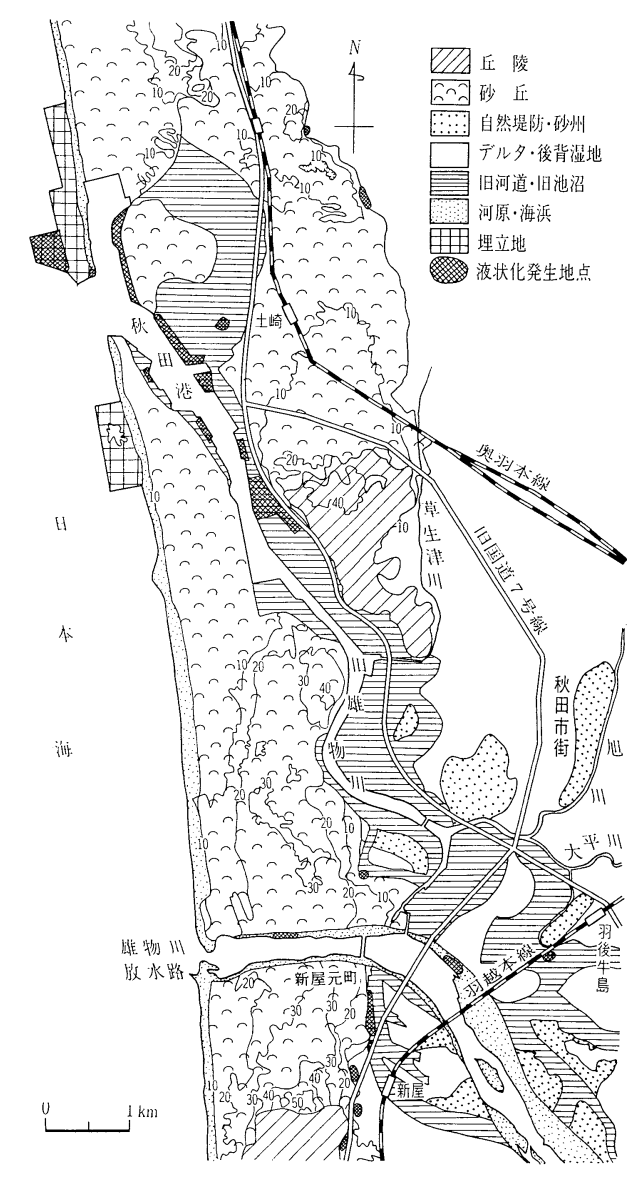

図-15雄物川河口付近の地形分類図と日本海中部地震に よる液状化発生地点 15$)$

なく，旧揖斐川およびその分流派川による堆積物（砂磁 層〜細砂層）の液状化と考えた方がより自然である。

この地域の場合，被圧地下水によって地盤には潜在的 に高い間隙水圧が加わっていたこと，しかも利根川扇状 地と同様, 後背湿地性の粘性土で覆われ地盤の排水性が 悪かったことが，河床砂啋層の過㮃間隙水圧の発生を助 長したと考えられた。

\section{3 能代・秋田平野}

秋田県の能代市から男鹿半島を経て秋田市にかけての 日本海沿岸地域には，海岸平野が連続している。これら の平野は濃尾平野や関東平野とは地形的様相が異なり, 海岸沿いの砂丘列と低湿なデルタ地帯で構成されている のが特徵である。この地域では, 古くは1694年（元禄 7 年)の能代地方の地震をはじめとして, 1810年羽後地震, 1896 年陸羽地震, 1939 年男鹿地震, 1964 年 5 月男鹿半 島沖地震，1964年 6 月新潟地震抒よび1983年日本海中 


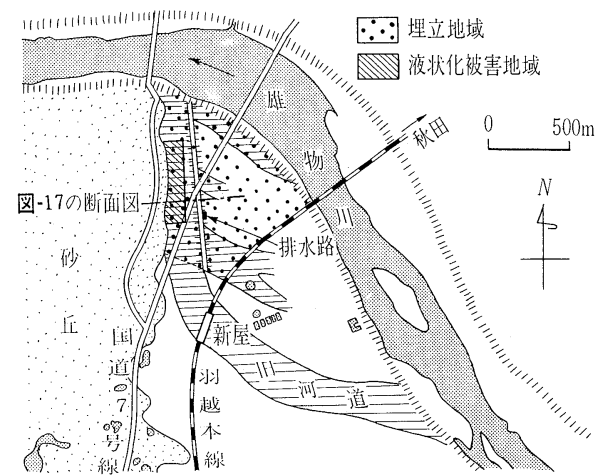

図-16 新屋元町付近の微地形と液状化被害地域15)

部地震で液状化が発生したと推定されている ${ }^{14)} 。$

図-13は，このうち能代から八郎潟西岸にかけての 地域の地形分類図と既往地震による液状化発生地点を示 している。液状化は，いずれの地震においても砂丘地帯 の内陸側縁辺部で起きていることがわかる。図-14に 砂丘地帯の模式的断面図を示したが，砂丘地帯と内陸側 の低地との境界部には，沼沢性の軟弱層の上にゆるい砂 丘砂が堆積している。これらの砂は，卓越風によって飛 ばされてきた砂丘砂や砂丘斜面を滑落した砂丘砂など, 2 次堆積の極めてルーズな砂である。そのうえ, 砂丘地 帯の内陸側縁辺部は, 大小多数の池沼が点在しているこ とからもわかるように, 砂丘地下水の湧泉帯に当たり地 下水位は極めて高い。さらに，緩斜面であるため，地盤 には潜在的にせん断力がかかっている。このため，液状 化の発生が直ちに地割れや側方流動などの变状につなが りやすく, したがって, 液状化による被害を増大させや すい地形条件であることも指摘できる。

図-15は，秋田市付近の地形分類図に，日本海中部 地震による液状化発生地点を重ねて示したものである。 液状化は秋田港付近の旧河道, 埋立地および砂丘の内陸 側縁辺部で発生していることがわかる。

図-16は，この地域の中でも，家屋等の被害が最も 著しかった秋田市新屋元町付近の微地形々液状化発生地 域の分布を示している。新屋元町一帯は, 昭和初期に雄 物川放水路を開削した際の土砂によって，雄物川の旧河 道を埋め立てた地域である。この旧河道は，元来は図に 示したような河幅を持って流れていたことが空中写真か ら読み取れるが，埋め立て以前の1912年（大正元年） 測図の $1 / 25,000$ 地形図を見ると, 旧河道の大部分は湿 地または水田であり，西端に細い流路を残すのみとなっ ている。今までにも旧河道での液状化は数多く報告され ているが，この地震で噴砂が認められたのは, 旧河道埋

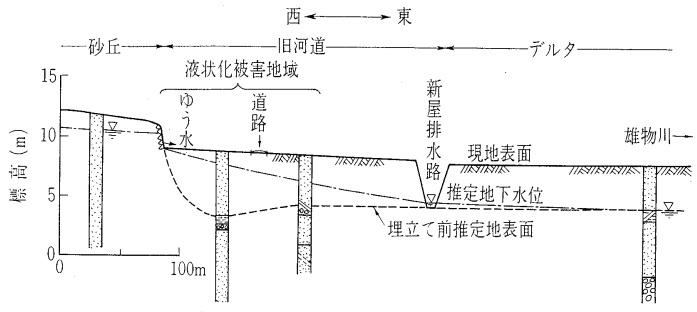

図-17 新屋元町付近の東西方向推定断面図 ${ }^{15)}$ (位置は図一16に示す)

立地のうち砂丘際の東西約 $100 \mathrm{~m}$, 南北約 $500 \mathrm{~m}$ の地域 に限定されていたことが注目された。

図-175) は, 新屋元町付近の東西方向推定断面図で ある。図に示したように，埋立層厚は旧河道部で5.5 m 程度，旧河道の東側に隣接するデルタ部分では $3 \sim 4 \mathrm{~m}$ である。埋立層は, 両地域とも $N$ 值 5 程度以下のゆる い砂丘砂が主体である。

一方, 地下水位に注目すると, 本来ならば旧地表面付 近にあるはずの水位が, 地震後被害地域内で行われた 2 本のボーリング調査結果によれば， G. L. $-1.0 \mathrm{~m}$ お よび $1.75 \mathrm{~m}$ となっており, 地下水位が旧地表面より 2〜4 $\mathrm{m}$ も上昇している。現地調査を行った結果, 西側 の砂丘崖からは湧水があり,これにより地下水位が埋立 層をで上昇したと推定された。すなわち, 図-17の推 定地下水位線に示したように, 砂丘から湧出した地下水 は旧河道側に流下するが，東側に排水路があるため，こ れに向かって地下水位は急激に低下する。また, 排水路 東側の地域では，排水路によって砂丘からの地下水の流 れが遮断されるため水位は埋め立て前とほとんど変わっ ていないと推定される。さらに，同じ砂丘際でも北側の 雄物川放水路に近い部分では, 砂丘地下水が放水路に放 出されるため旧河道側への地下水の流下量は少なく, し たがって地下水位も南側の被害地域に比べて低いと考え られる。

以上から推察すると, 新屋元町では地下水位の高低が 液状化被害の有無の分岐点になったと考えられるが，こ の地下水条件を支配したものは，言うまでもなく周辺の 地形・地質的環境条件である。

\section{4. 結 び}

液状化は同じ地震動の条件下では一般に，(1)飽和地盤 の細粒土（0.074 $\mathrm{mm}$ 以下の粒径を持つ土粒子）含有率 が低いほど，(2)飽和地盤の標準貫入試験の N 值が小さ いほど, (3)地下水位が地表面に近いほど生じやすいと考 えられている。本シリーズの総論16)で既に述べられて 
いるように，上記のような地盤や土の土質工学的性質を 支配しているのは, 土や土層の成因と, その後の地形・ 地質学的プロセスである。

例えば, 粒径の及から見ると, 液状化が最も生じやす いのは, 粒径のそろった細砂や中砂，それも角ばってい ない砂である。対象地域内にこのような砂が堆積する範 囲を探すには，土質工学ではまずボーリング調査を高密 度に行い, 各調査地点の土のサンプルについて粒度試験 を行う。莫大な費用と時間がかかる作業である。しか し, 地形・地質学的手法により，その分布範囲を推定す ることは極めて容易である。上記のような性質の砂が最 も生成されやすい所が砂丘であることは, 総論16)でも 触れられている。

一方, 河川流域で，液状化を起こしやすい粒度配合不 良な砂，すなわち分級作用が完全に行われた粒径のそろ った砂の分布範囲を探すのも, 同様に容易である。大河 川中流部の自然堤防や旧河道に, このような砂が多く堆 積している。前章で述べた事例からもわかるように, 砂 丘（ただし地下水位の高い縁辺部や砂丘間低地）, 自然 堤防，旧河道などでは液状化の発生事例が極めて多い。

また，その場所の地形・地質的条件だけでなく，周囲 の地形・地質的環境条件が液状化の発生に強く影響して いると思われる場合がある。前述の濃尾平野の大垣付近 や秋田平野の新屋元町における事例がその好例である。 このような被害事例の分析は, 詳細な土質工学的調査と 平行して, 地形・地質学的観点加らの大局的・総合的な 考察がなされるべき典型例と言えよう。

以上のごとく, 液状化問題も地形学・地質学々土質工 学の両方の知見と技術が, ともに発揮されるべき接点の 一例である。

\section{参 考 文 献}

1) 式 正英 (1962)：浅層地質学と微地形学の応用, 建築雑
誌, Vol. 77, No, 11, pp. 688-693.

2) 若松加寿江 (1990)：日本液状化履歴図, 第 8 回日本地震 工学シンポジウム講演集, pp. 915-920.

3）若松加寿江（1990）：わが国における液状化履歴の特徵, 日本建築学会大会学術講演梗概集, Vol. B, pp. 15731574.

4）門倉三能（1925）：埼玉県地震調査報文, 関東地震調查報 告, 第一, 地質調查所, pp. $1-30$.

5）大矢雅彦 (1975)：地形分類による関東地方の河成平野の 比較研究, 日本大学地理学科五十周年記念論文集, pp. 75 $-89$.

6）建設省土木研究所（1981）：河道特性論ノートI一荒川 中流部の河道特性と河川処理一, 土研資料第 1745 号, pp. $18-32$.

7) 大矢雅彦 (1961)：中川流域低湿地の地形分類と土地利 用, 科学技術庁資源局資料第 40 号, pp. 17-29.

8）中山正民・原高則・小野口勲（1979）：利根川中流及び中 川流域における沖積平野の地形, 埼玉大学紀要教育学部 (数学・自然科学), 第 28 巻, pp. $81-89$.

9）植野隆寿・石井徳治（1931）：熊谷町より妻沼町に至る利 根川沿岸の震域踏査報告, 験震時報, Vol. 5 , No. 2 , pp. $342-344$.

10）資源科学研究所（1969）：埼玉県地下水水理調査報告書, pp. $14-15$.

11）大矢雅彦 - 小池邦夫 (1976)：濃尾平野河川地形図, 建設 省木曾川上流工事事務所.

12）村下敏夫・比留川 貴 - 尾崎次男 (1954）：濃尾平野の工 業用水源地域調查報告, 一大垣自噴带を中心として一, 東海地域調査第 3 報, 地質調查所月報, 第 5 巻, 第 12 号, pp. 1-12.

13）古藤田喜久雄 - 若松加寿江（1987）：濃尾平野北西部大垣 付近の液状化履歴地点之地形・地盤条件々の関係, 第22 回土質工学研究発表会発表講演集, pp. $767-770$.

14）古藤田喜久雄・若松加寿江（1985）：青森県西部および秋 田県北西部地域の液状化履歴とその特徵, 第20回土質工 学研究発表会発表講演集, pp. 801-804.

15）古藤田喜久雄・若松加寿江（1984）：日本海中部地震によ る液状化現象と地形条件との関係, 土と基礎, Vol. 32 , No. 9 , pp. $59-63$.

16）池田俊雄 (1990): 地質学々土質工学の接点, 応用地質, Vol. 31, No. 3, pp. $31-40$.

（1990年11月 26 日受付, 1990年12月12日受理） 